\title{
Improving the Human Resource Management System in the Moscow Region Municipality
}

\author{
Olga N. Gromova*, Gabdelakhat R. Latfullin, Kazi N. Rustamov, Galina M. \\ Sundukova
}

State University of Management, Moscow, Russian Federation

* Corresponding author. E-mail: Olg.gromova2011@yandex.ru

\begin{abstract}
The purpose of the article is to reveal the developed measures to improve the effectiveness of the human resource management system in the municipalities of the Moscow region (MO) using an innovative approach and the use of competency models. The article presents the results of research conducted on the analysis of the state of personnel management in organizations of the Moscow region using an innovative approach and the development of a number of competency models. A number of measures are proposed to improve the effectiveness of the human resource management system in municipalities, in particular: the introduction of KPIs-key performance indicators, i.e. the reporting system of targets and the budget of the organization (Introducing KPIs, 2008); these indicators are quantitative parameters that are previously identified, agreed and reflect the main success factors of the Department or division. In personnel management, these indicators include the performance of government agencies and their divisions, the effectiveness of civil servants, and staff satisfaction with their work [1]. The feasibility of implementing this system is determined by the need to create a clear and transparent system not only for employees, but also for residents of the region. A system of applying the competence approach is proposed [2], combined with a system for evaluating employees in the form of applying KPI. A system of non-material incentives in such a division is proposed; recommendations are formulated for the creation and development of a personnel reserve; a system of training and development of personnel, the creation of an internal training center.
\end{abstract}

Keywords: management, personnel, resources, incentives, motivation, model, indicator, mechanism, competence

\section{INTRODUCTION}

The human resource management mechanism is a set of organizational, economic, material, technical, and sociopsychological tools and methods for encouraging staff to work effectively to ensure the achievement of the goal of motivational policy [3]. The human resource management mechanism in an enterprise is aimed not only at survival, but also at achieving success in a competitive environment [4]. For human resources management, such tools as innovative approach and human resources technologies are used. HR technologies are "a set of consistently performed actions, techniques, operations that allow you to either get information about the capabilities of a person, or create the conditions required for the organization, or change the conditions for using human resources" [5]. The main tasks of the human resource management mechanism are to develop each employee's understanding of the essence and meaning of motivation; to form democratic approaches to personnel management for managers using modern methods of motivation [6]. In this paper, we will understand labor resources as a set of functioning and potential labor force, the quantitative and demographic framework of which depends on the market form of production and the level of development of productive forces [7]. Competence models for employees of organizations were developed, which allowed both applying the appropriate motivation system and evaluating their performance.

\section{METHODOLOGY}

The methodology of studying the problem consisted of analysing statistical data using the method of moment supervision activities of employee organizations of the Moscow region, the application of the competence-based qualification model municipal employees $\mathrm{MO}$, which allowed to identify the willingness of future leaders to management activities [7]. The quantitative analysis was conducted by comparing the actual number of employees by category and profession with the planned need. To analyze the qualitative composition of the labor force, such parameters as the level of education and 
qualifications, profession, gender, age, and work experience were considered. The level of education is one of the indicators of the quality of labor resources $[8,9]$. A number of indicators, mainly the tariff category, were used to study the qualification composition of the labor force. Human resources by profession and occupation allow us to study the distribution of employees by specific forms of work. In General, the main tasks of the human resource management mechanism, both with the traditional and innovative approach, are: the formation of each employee's understanding of the essence and meaning of motivation; training of the organization's personnel in the psychological basics of organizational communication; the formation of democratic approaches to personnel management by managers using modern methods of motivation [10].

\section{DISCUSSION}

An analysis of the materials and results presented in this research publication allows us to draw the following conclusions, which are based on the above provisions. The following components of the proposed innovative approach were highlighted:

1) implementation of KPIs-key performance indicators, i.e. a system for reporting the organization's targets and budget [11]. The main goals of implementing key performance indicators in the public sector are: stimulating the efficiency and quality of work of employees of structural divisions, analyzing the compliance of the functions performed by employees with the public needs of visitors; developing a feedback system for officials with consumers of public services. The task of maintaining the composition of qualified employees at the required level includes the following indicators: identifying the percentage of specialists who have recently passed certification; determining the percentage of specialists who have received advanced training based on the results of certification, the percentage of those who have completed training (by type of relevant courses); calculating the average cost of development of one employee (by category of employees) [12, 13].

2) Development of a personnel management strategy. One of the tools for successful functioning is modern management technologies, in particular, strategic management of the entire organization and various types of personnel management strategies. The strategy of personnel management consists in determining the ways to develop the competencies of the staff, each employee individually and the organization as a whole for the implementation of strategic goals. [14]. The proposed system of staff motivation is aimed at developing a sense of belonging to this organization. In addition, according to the conducted empirical research, it was proposed to use methods of human resource management using an innovative approach in the form of: setting clear and achievable goals for employees; developing programs to inform employees about the company's activities; officially recognizing the merits of each employee; creating opportunities for professional training of employees; providing opportunities for career growth to employees; encouraging employees with flexible work schedules; regular corporate events $[15,16]$.

We used the results of research conducted at the Department of management theory of GUU [2] to create a system of personnel motivation based on a competencybased approach. The essence of this approach is as follows. The basis of personnel management is the concept of competence, which is understood as the unity of knowledge, skills that are inherent in each employee, behavior patterns. The set of required knowledge and skills is defined by the organization as a condition for achieving the set overall goals. A set of employee competency models is developed to implement the tasks it faces, based on the overall goal of the organization [6]. Employees are evaluated in accordance with these models, and then the appropriate training system is developed. An example of the component competencies is shown in table 1

Table 1 An example of the components of the competence model of the head of the division

\begin{tabular}{|c|c|c|}
\hline Skills & Pattern of behavior & Knowledge \\
\hline Negotiation & Hear and present information & Official duties \\
\hline Convictions' & $\begin{array}{c}\text { Evaluate, be attentive to visitors and } \\
\text { employees }\end{array}$ & $\begin{array}{c}\text { Specifics of interaction with the } \\
\text { population }\end{array}$ \\
\hline Activity analysis & Act in work situations & Internal reporting documents \\
\hline $\begin{array}{c}\text { Communication with employees and } \\
\text { visitors }\end{array}$ & Teach and train employees & $\begin{array}{c}\text { Terms of interaction with the } \\
\text { population }\end{array}$ \\
\hline Planning activities & Show the initiative & \\
\hline
\end{tabular}


When creating competency models, the following factors are taken into account: the purpose and objectives of the employee's position, the required work experience, and the level of adaptation of the employee to work. The study combined the application of competency models with employee evaluation using the KPI method described above [17]. The components of the competence models are the criteria for selecting employees, drawing up their training program (in accordance with Tuning Education programs in Russian, 2008, and implementing the assessment [18].

Career charts are compiled for employees who have successfully passed the assessment.

\section{RESULTS}

The career program covers the list of positions arranged in ascending order, highlighting which positions employees can consistently occupy, as well as the necessary internships and professional development [19]. It was proposed to introduce flexible working hours for managers and specialists. Employees can choose the start and end time of work, as well as the start and end time of the lunch break at their own discretion [12]. However, these categories of employees must necessarily be at the workplace from 11.00 to 16.00 , the working time established by law (40 hours) must be worked per week, and the working time can not exceed 12 hours per day [6]. The use of flexible modes of working time has positive consequences for workers and for the organization: allows employees to balance work and family or studies, reduces tension of workers and the number of stressful situations, reduces unproductive losses of working time, reduces absenteeism, tardiness and leaving the workplace before the end of the day, take into account the daily changes of the health of the employee, increases productivity, improves the quality of work, creates employee loyalty to the company $[4,20]$.

Analysis of social responsibility has provided the opportunity to identify the main effective methods of human resources management in the enterprise using innovative and content store approach to the staff of municipal education were modeled competencies of employees, implemented employee perception of personality leadership, respect shown to employees, their needs and interests; create a safe, comfortable work environment; implemented the provision of moral and social protection of the workforce.

\section{CONCLUSIONS}

Analysis of materials and results of the present study allows to conclude that the human resource management system was developed in the following sequence: diagnostics produced by the current system of human resource management; States the purpose of the motivational policy and strategy of personnel management; the proposed system of key performance indicators of an organization that contributes to the quality of the work of the organization, its individual departments and employees. [21]. The developed model of competencies, the analysis of compliance of the functions performed by employees, the public needs; the proposed system of feedback officials with the consumers of public services; the proposed system of moral incentives; it built a system of material incentives; the developed system of internal regulations in the field of mechanism of human resource management.

\section{THE PERSPECTIVES OF THE RESEARCH}

In the future, in order to automate the process of personnel management, it is planned to start work on the implementation of the SAP-ERP system (system Applications and Products Enterprise Resource Planning), i.e. the enterprise resource planning system that manages all the processes of the organization. Software products that automate individual functional tasks are being developed. These programs are the end product, regardless of the level of development [1]

\section{ACKNOWLEDGMENT}

The authors Express their sincere gratitude to the organizers and participants of the international conferences: "Actual problems of management", "Edcrunch", who kindly provided panels for discussion and testing of developments, as well as forum materials used in the process of adapting the provisions and developing a strategy for further development of the research presented in this publication, the administration of the State University of management for the opportunity to conduct this research.

\section{REFERENCES}

[1] A. Raichenko, G. Avetisyan, O. Gromova, G. Latfullin, L. Orlova, F. Ibyatov, Interviewer and public organizations, in: Proceedings of the International Conference on Man-Power-Law-Governance: Interdisciplinary Approaches», 2019, pp. 425-430. DOI: https://doi.org/10.2991/mplg-ia-19.2019.79 
[2] O.N. Gromova, Motivation for personnel on the basis of competence approach/ XXI century initiatives 3 (2009) 38-44.

[3] A. Budarina, Digital Quality Management in Higher Education, Higher Education in Russia, 2019.

[4] R. Baldridge, 3 Ways the Digital Revolution Is Impacting Human Resources, 03.05.2018, Available at: https://www.inc.com/hr-outsourcing, 3-ways-digitalrevolution-is-impacting-human-resources.html.

[5] M.S. Agafonov, A.A. Belomyttseva, Management of labor behavior as a factor of increasing labor motivation, Modern science-intensive technologies 101 (2018) 132-133.

[6] S. Shahnawaz, Impact of Tangible and Intangible Rewardson Organizational Commitment: Evidence from the Textile Sector of Pakistan, American Journal of Industrial and Business Management 5 (2015) 138147.

[7] J. Bloomberg, Digital Transformation by Any Other Name?, Forbes (2014), Available at: https://www.forbes.com/sites/jasonbloomberg/2014/07/ 31/digital-transformation-by-any-othername/\#6a71306f6b99.

[8] B. Kumar, Digital transformation and its impact on human resource management: A case analysis of two unrelated businesses in the Mauritian public service, International Journal of Novel Research in Interdisciplinary Studies 3 (2016) 1-10.

[9] M. Mosca, F. Pastore, Wage effects of recruitment methods, IZA Working Paper, 2008.

[10] V.I. Gerchikov, HR management: the employee is the most effective resource of the company, INFRA-M, 2017.

[11] D. Owens, A. Keegan, Introducing KPI in the government sector. Possible futures for the HR functions, 2008.

[12] Digital HP: Platforms, people, and work. 2017 Global Human Capital Trend, 2017, Available at: http://dupress,com/dup-us-en, focus/human-capitaltrends.

[13] S. Hidi, J.M. Harackiewicz, Motivating the corporatelly unmotivated: A critical issue for the 21st century, Review of Educational Research 70(2) (2013) 151-179.
[14] T.H. Davenport, M. Leibold, S.C. Voelpel, Strategic Management in the Innovation Economy: Strategic Approaches and Tools for Dynamic Innovation Capabilities, Wiley, 2006.

[15] D. Lahl, How a Platform Approach Can Deliver Unified Digital Experiences, 2019, Available at: https://www.thedigitalenterprise.com/articles/ customer-experience-social-marketing/how-a-platformapproach-can-deliver-unified-digital-experiences/.

[16] A. Tikhomirov, Legal Administration in the Economy: Actual Problems, Yustitsiya, 2018, Available at: https://ozonst.cdn.ngenix.net/multimedia/1020633485.pdf.

[18] S. Ghoshal, Imagining the Digital future: How digital themes are transforming companies across industries, 2015, Available at: https://www.yumpu.com/en/document/read/54458484.

[19] P. Kotler, K.L. Keller, Library of Congress Cataloging-in-Publication Data: Marketing management - II, 2012.

[20] HR-Portal: Community of HR managers, Available at: http://hr-portal.ru/tags/podborpersonala?utm_source=hrp\&utm_medium=block\&utm _campaign=recruit.

[22] J. Bersin, The organization of the future: Arriving now," Global Human Capital Trends 2017: Rewriting the rules for the digital age, Deloitte University Press, 2017, Available at: https://www2.deloitte.com/us/en/insights/focus/human-capital-trends/2017/organization-of-thefuture.html.

[23] T.H. Eliot, Governing America: The Politics of Free People. National, State and Local Government Edition, 2008. 